\title{
Laboratory bioassays of new synthetic and microbial insecticides to control Eucalyptus tortoise beetle Paropsis charybdis
}

\author{
T.M. Withers ${ }^{1}$, M.C. Watson ${ }^{1}$, M.S. Watt ${ }^{1}$, T.L. Nelson ${ }^{2}$, L.A. Harper $^{2}$ and \\ M.R.H. Hurst ${ }^{2}$ \\ ${ }^{1}$ Scion, Private Bag 3020, Rotorua 3046, New Zealand \\ ${ }^{2}$ AgResearch Lincoln, Private Bag 4749, Christchurch 8140, New Zealand \\ Corresponding author: toni.withers@scionresearch.com
}

\begin{abstract}
Paropsis charybdis, or eucalyptus tortoise beetle, is (one of) the most significant pests of eucalypts in New Zealand. It severely defoliates Eucalyptus nitens and Eucalyptus globulus plantations, leaving heavily-damaged trees with reduced growth and poor form. Laboratory bioassays of new synthetic and microbial insecticides were undertaken to identify management options compatible with biological control. The current insecticide used for operational control, alpha-cypermethrin, was a positive control. Of the products tested, spinetoram (Sparta) gave the most promising results (100\% mortality after 14 days) for control of adult $P$. charybdis. Spinetoram and spinosad (Success Naturalyte), the microbial control agents Beauveria bassiana (F305 ex Botanigard) and Bacillus thuringiensis var tenebrionis, and the enterobacterium Yersinia entomophaga, all resulted in high mortality of larval $P$. charybdis after 4 days. Targeting larvae alone may not be economically viable, leaving spinetoram as the only possible additional insecticide for managing $P$. charybdis. Potential barriers of cost, application and non-target impacts are yet to be addressed.
\end{abstract}

Keywords alpha-cypermethrin, Bacillus thuringiensis, Beauveria bassiana, spinetoram, spinosad, Yersinia entomophaga.

\section{INTRODUCTION}

Of Australian origin, the chrysomelid beetle Paropsis charybdis Stål, commonly known as the eucalyptus tortoise beetle, has been established in New Zealand since 1916 (White 1973). Since then, $P$. charybdis has become the most significant defoliator of adult foliage of eucalypts. The beetle severely defoliates Eucalyptus nitens (Deane et Maiden) Maiden plantations throughout New Zealand, with heavily damaged trees having reduced growth and form (Bain 1977). Repeated defoliation can kill trees. The beetle has two complete generations per year in New Zealand (Murphy \& Kay 2000) and also feeds on other commercially important eucalypt species including E. viminalis Labill. and E. globulus Labill.

In New Zealand, $P$. charybdis is controlled on an as-needed basis by aerial spraying with synthetic pyrethroids, most commonly alphacypermethrin. Alpha-cypermethrin is a broadspectrum synthetic pyrethroid that is very effective against target insect pests, but also kills native insects in the spray zone including 
beneficial predators and biological control agents (Greener \& Candy 1994; Loch 2005). An alternative method of managing $P$. charybdis in eucalypt stands in New Zealand would benefit FSC-certified plantations as alpha-cypermethrin is not acceptable to the Forest Stewardship Council (FSC). The FSC aims to minimise negative environmental and social impacts of pesticide use whilst promoting economically viable management of the world's forests. This includes the avoidance of 'highly hazardous' pesticides, and instead promotes 'non-chemical' methods of pest management as an element of an integrated pest management strategy (FSC 2007). A number of Eucalyptus plantations in New Zealand are managed under FSC, and currently have a "derogation", which is a permission to use alpha-cypermethrin to manage outbreaks of $P$. charybdis. Should this derogation fail to be renewed in the future, New Zealand's plantation hardwood industry would require some practical and cost-effective alternative pesticides to alpha-cypermethrin for managing $P$. charybdis outbreaks. The recent increase in planting of E. nitens in the North Island, and some renewed interest in planting other species of eucalypt suitable for dry climates, means an environmentally-acceptable method of control for this pest, preferably one with low beneficial arthropod toxicity, may be welcomed by more than just FSC-certified plantations.

A series of laboratory bioassays of products, both microbials and new generation chemicals belonging to the spinosad group, to control $P$. charybdis in New Zealand eucalypt plantations that would meet Forest Stewardship Council (FSC) recommendations was carried out. All products were tested by exposing $P$. charybdis adults and larvae to treated $E$. nitens foliage. The equivalent of the current operational application rate of alpha-cypermethrin was used as a positive control.

\section{MATERIALS AND METHODS}

Five bioassays were undertaken - three bioassays were based on a spray application to branches, and two were based on individual leaf-dipping.

\section{Insects}

Adult $P$. charybdis were field collected from Eucalyptus plantations in the Bay of Plenty and Taupo region, from October to December in 2010 (used in bioassays 1, 4 and 5) and 2012 (used in bioassay 2). These were maintained in large perspex cages placed in a room at $18^{\circ} \mathrm{C}$ and $65 \% \mathrm{RH}$. The beetles were supplied freshly cut branches of $E$. nitens foliage bearing new growth with the branch bases sitting in water. Branches with foliage were changed three times weekly and egg batches removed and placed in Petri dishes within a sealed plastic container in a chill room (at $4^{\circ} \mathrm{C}$ ) until needed. First instar larvae were obtained for spray trials by removing egg batches from the chill room, after 1-20 days storage, and transferring them to the $18^{\circ} \mathrm{C}$ room, 5 days before they were needed for bioassays. In March 2013 adults were collected from E. nitens trees in Happy Valley forest, Longwoods, Southland, and immediately couriered to Rotorua, after which they were maintained at $18^{\circ} \mathrm{C}$ until used 1 week later in bioassay 3 .

\section{Bioassays 1, 2 and 3}

Five products were tested in this trial series (Table 1). They included the active ingredients spinosad (Success Naturalyte ${ }^{\mathrm{TM}}$, Dow Agrosciences) and spinetoram (Sparta ${ }^{\mathrm{TM}}$, Dow Agrosciences) that are derived from a family of natural products obtained by fermentation of the bacterium Saccharopolyspora spinosa. In addition, two strains (F305, Beaugenic ${ }^{\mathrm{TM}}$ ) of the entomophagous fungus Beauveria bassiana (Hypocreales: Cordycipitaceae) (Table 1) were tested. The F305 (or GHA) strain was isolated and maintained by AgResearch from the product BotaniGard ${ }^{\circledR}$ ES, which was obtained from Elliott Chemicals in the 1990s. The Beaugenic ${ }^{\text {TM }}$ strain is a patented indigenous strain of the same entomopathogenic fungus, Beauveria bassiana, but one that has been selected for its virulence towards thrips. However, the Beaugenic ${ }^{\mathrm{TM}}$ used in this trial was reformulated by Crop Solutions Ltd to make it more effective against beetles (Travis Glare, Lincoln University, personal communication). All products were compared against a standard rate of alpha- 
cypermethrin (Dominex 100 ${ }^{\mathrm{TM}}$, Elliott Chemicals Ltd) as a positive control (Table 1) and foliage sprayed with distilled water as a negative control. In bioassay 3 spinetoram was further assessed against adult $P$. charybdis at a range of dilutions (3-48 g/ha) to determine a dose-response curve. Apart from including the adjuvant DuWett at $0.2 \%$ by volume, the methods and procedures followed in bioassay 3 were otherwise identical to bioassays 1 and 2 .

All treatments were applied in water at a range of concentrations using a calibrated precision track sprayer (Plant Protection Chemistry NZ, Rotorua). For bioassay 1 (2010) all treatments were applied at a rate equivalent in total volume to 150 litres/ha using two Turbo Teejet Induction (TTI 100015) nozzles operated at $240 \mathrm{kPa}$ to produce an extra coarse droplet spectrum with a VMD of approximately $450 \mu \mathrm{m}$ (Table 1). This follows best practice for minimising spray drift via aircraft application. In bioassays 2 and 3, similar nozzles (Teejet TJ60 11002VS) were operated at $250 \mathrm{kPa}$ to produce fine droplets applied at the equivalent rate of 50 litres/ha. This was the lowest volume the precision track sprayer could deliver and is closer to the industry current practise of fine droplets delivered at 5 litres/ha. The track sprayer was calibrated using the colorimetric method with tartrazine food dye at $10 \mathrm{~g} /$ litre. Dye recovery was measured by wash off in $50 \mathrm{ml}$ distilled water. UV absorbance of each sample was measured at $427 \mathrm{~nm}$ with a PG Instruments UV-VIS spectrophotometer.

All treatments were applied by placing E. nitens foliage on a bench over which the mechanised track sprayer boom delivering the spray then moved. Stems, consisting of 4-6 newly flushed leaves and 2 fully expanded leaves, were supported in saturated florist foam for spraying. Foliage was allowed to air dry, before being transferred to a constant temperature room $\left(18^{\circ} \mathrm{C}\right.$ and $\left.65 \% \mathrm{RH}\right)$. For the feeding bioassays the treated foliage was placed into a plastic container with the cut stem sitting in water below, while insects used in the bioassay were partitioned in a dry portion sitting above.

For each bioassay, four (bioassay 1) or five (bioassays 2 and 3) P. charybdis adults and/or five $P$. charybdis first instar larvae were placed on the foliage within $60 \mathrm{~min}$ of spraying (Table 1). Each container was inspected at 24 and $48 \mathrm{~h}, 4$, 7, 10 and 14 days after spraying. During each inspection, the number of surviving adults or

Table 1 Rates equivalent to values per ha of active ingredient applied to foliage in spray bioassays 1 and 2 with both first instar larvae and adult P. charybdis. The adjuvant BondXtra (Elliott Chemicals Ltd) was only applied in bioassay 1 at $0.2 \%$ by volume.

\begin{tabular}{|c|c|c|c|c|}
\hline Active ingredient & $\begin{array}{c}\text { Volume litres/ } \\
\text { ha }\end{array}$ & Low & Medium & High \\
\hline \multicolumn{5}{|l|}{ Bioassay $1^{1}$} \\
\hline alpha-cypermethrin & 150 & - & $30 \mathrm{~g} / \mathrm{ha}$ & - \\
\hline spinosad & 150 & $72 \mathrm{~g} / \mathrm{ha}$ & $144 \mathrm{~g} / \mathrm{ha}$ & $288 \mathrm{~g} / \mathrm{ha}$ \\
\hline $\begin{array}{l}\text { Beauvaria bassiana F305 } \\
\left(2 \times 10^{9} \mathrm{cfu} / \mathrm{g}\right)\end{array}$ & 150 & $1.67 \mathrm{ml} /$ litre & $3.3 \mathrm{ml} /$ litre & $6.6 \mathrm{ml} /$ litre \\
\hline $\begin{array}{l}\text { Beauvaria bassiana } \\
\text { Beaugenic }\left(2 \times 10^{9} \mathrm{cfu} / \mathrm{g}\right)\end{array}$ & 150 & $1.67 \mathrm{ml} /$ litre & $3.3 \mathrm{ml} /$ litre & $6.6 \mathrm{ml} /$ litre \\
\hline \multicolumn{5}{|l|}{ Bioassay 2} \\
\hline alpha-cypermethrin & 50 & - & $30 \mathrm{~g} / \mathrm{ha}^{2}$ & - \\
\hline spinosad & 50 & $12 \mathrm{~g} / \mathrm{ha}^{2}$ & $24 \mathrm{~g} / \mathrm{ha}$ & $48 \mathrm{~g} / \mathrm{ha}$ \\
\hline spinetoram & 50 & $12 \mathrm{~g} / \mathrm{ha}^{2}$ & $24 \mathrm{~g} / \mathrm{ha}$ & $48 \mathrm{~g} / \mathrm{ha}$ \\
\hline
\end{tabular}

${ }^{1}$ Data also appear in Future Forests Research 2011 confidential report number FFR- DS036.

${ }^{2}$ Insufficient adult beetles were obtained so only larvae were tested for these rates. 
larvae was recorded. Larvae were considered to have died once they failed to respond by exerting their tubercles to a touch on their dorsal surface with one strand of a camel hair brush. Adults were considered to have died once their legs were no longer moving. To prevent any mortality due to lack of food, additional unsprayed foliage was added to all containers with surviving larvae or adults every $48 \mathrm{~h}$ or when all suitable foliage within a container had been consumed.

\section{Leaf dip bioassays 4 and 5}

Leaf dip bioassays with the microbes were carried out within the Lincoln AgResearch containment facility for microorganisms (facility \#480), as neither formulation is registered for field release under New Zealand's Hazardous Substances and New Organisms (HSNO) Act 1996.

Inbioassay 4, Yersinia entomophaga(typestrain MH96 $^{\mathrm{T}}$ ) (Proteobacteria: Enterobacteriaceae) (Hurst et al. 2011) was grown in Luria-Bertani (LB) broth at $30^{\circ} \mathrm{C}$ with shaking at $250 \mathrm{rpm}$ in a Raytek orbital incubator. Enumeration of colony forming units (cfu) was carried out using serial dilutions in $0.1 \mathrm{M}$ phosphate buffer (10 mM sodium phosphate buffer, $\mathrm{pH}$ 7.4; $0.65 \mathrm{mM} \mathrm{K}_{2} \mathrm{HPO}_{4}, 0.35 \mathrm{mM} \mathrm{KH_{2 }} \mathrm{PO}_{4}$ ) spread plated onto $\mathrm{LB}$ agar plates incubated at $30^{\circ} \mathrm{C}$ for $48 \mathrm{~h}$. Mortality was assessed by leaf dip bioassay at five different rates equivalent to between $5 \times 10^{8} \mathrm{cfu} / \mathrm{ml}$ and $1 \times 10^{5} \mathrm{cfu} / \mathrm{ml}$.

In bioassay 5, Bacillus thuringiensis var tenebrionis originally isolated by AgResearch from a liquid formulation supplied by Mycogen Corporation 1995, was grown in LB broth at $30^{\circ} \mathrm{C}$ with shaking at $250 \mathrm{rpm}$ in a Raytek orbital incubator for $90 \mathrm{~h}$. The broth was examined under phase contrast (Olympus $\mathrm{BH} 2)$ to confirm formation of the Cry toxin bodies and spores, and enumerated as per the $Y$. entomophaga to determine cfus. Mortality was assessed by leaf-dip bioassay at four different dilutions equivalent to between $3 \times 10^{8}$ spores $/ \mathrm{ml}$ and $3 \times 10^{5}$ spores $/ \mathrm{ml}$.

In both bioassays 4 and 5 the rates were prepared from the concentrated active ingredient by performing serial dilutions using $0.01 \%$
DuWett (Elliot Chemicals Ltd), which acted as an adjuvant to aid adhesion to the Eucalyptus leaves. The concentrates then had DuWett added at $0.01 \%$ by volume. A negative control of $0.01 \%$ DuWett in distilled water was included for all bioassays.

For bioassays 4 and 5, fresh, juvenile individual leaves of Eucalyptus globulus Labill. or Eucalyptus leucoxylon F.Muell. (these host species were utilised due to availability of live material at the Lincoln site) cut immediately prior to the assay were dipped in the dilutions described above and allowed to air dry. Individual leaves were placed in a $90 \mathrm{~mm}$ diameter Petri dish lined with dampened filter paper. For each bioassay either five $P$. charybdis first instar larvae or four $P$. charybdis adults were added to each dish. Four replicate dishes (larvae) or five replicate dishes (adults) per treatment were set up. Dishes were held at $20^{\circ} \mathrm{C}$ and inspected daily for feeding activity and mortality. The number of surviving adults or larvae was recorded. Larvae were considered to have died once they failed to respond by exerting their tubercles to a touch on their dorsal surface with one strand of the camel hair brush. Adults were considered to have died once their legs were no longer moving.

\section{Statistical methods}

Data from all bioassays were analysed separately. A mixed effects model that included treatment as a fixed effect and replicate as a random effect was used to analyse the complete data set (SAS Institute Inc. 2008). The effect of treatment on mortality was analysed at day 4 for larvae and at day 10 or 14 for adults, and multiple comparisons were undertaken using the least significant difference (LSD) test.

For bioassay 3 a dose response function that related spinetoram rate $(r)$ to proportion mortality $(M)$ on day 14 was fitted to the logtransformed data using the Chapman Richards three parameter sigmoidal equation, described below,

$M=a(1-\exp (-b r))^{c}$

where $a, b$ and $c$ are empirically derived parameters.

Analysis of bioassays four and five were performed with the Fisher's exact test, by 
comparing mortalities between the dilutions. The dose-response curves of bioassays on larvae showing a significant treatment effect were estimated with Minitab 15 (Minitab Inc., 2006), by fitting a probit function to the data, using $\log _{10}$-transformed dilution levels.

\section{RESULTS}

\section{Bioassay 1}

Insecticide treatment had a highly significant effect $(\mathrm{P}<0.001)$ on mortality of larval $P$. charybdis with alpha-cypermethrin and spinosad killing all larvae within $24 \mathrm{~h}$. The effects of B. bassiana F305 took longer to be revealed in larval mortality, so the day 4 data are presented as the best summary. Larvae were not susceptible to $B$. bassiana ex Beaugenic at any of the rates applied or at any time after spraying (Table 2). Reflecting the slower mortality effects from the different products, there was a significant effect of day $(\mathrm{P}<0.001)$ and an interaction between day and treatment $(\mathrm{P}<0.001)$ (data not shown). Multiple range tests on the data reveal that by day 4 there were no significant differences in larval mortality between the B. bassiana F305, the spinosad and the positive control (Table 2).
Adult mortality showed a highly significant effect of day $(\mathrm{P}<0.001)$, and insecticide treatment $(\mathrm{P}<0.001)$ and an interaction between them $(\mathrm{P}<0.001)$ on mortality of adults (data not shown). Spinosad induced adult $P$. charybdis mortality was the same as that achieved by alpha-cypermethrin, but only at the very high application rates and after 10 days (Table 2). Adult P. charybdis were not susceptible to either of the $B$. bassiana strains: Beaugenic or F305 (Table 2).

\section{Bioassay 2}

Insecticide treatment had a highly significant effect $(\mathrm{P}<0.001)$ on mortality of larval $P$. charybdis with almost all larvae treated with alpha-cypermethrin, spinosad or spinetoram dying within $48 \mathrm{~h}$ compared with $<20 \%$ mortality of controls (data not shown). Day $(\mathrm{P}<0.001)$ and an interaction between day and treatment $(\mathrm{P}<0.001)$ were also highly significant. Multiple range tests on the data reveal that larvae were highly susceptible to spinosad and spinetoram at all the rates applied, with complete mortality by day 4 (Table 3).

Similarly there was highly significant effect of day $(\mathrm{P}<0.001)$, insecticide treatment $(\mathrm{P}<0.001)$

Table 2 Mortality (Mean proportion $( \pm \mathrm{SE})$ ) of Paropsis charybdis larvae and adults in response to treatment in bioassay 1 . Means sharing letters are not significantly different at $\mathrm{P}<0.05$ for larvae and adults, respectively.

\begin{tabular}{|c|c|c|c|c|}
\hline & \multicolumn{2}{|l|}{ Larvae Day 4} & \multicolumn{2}{|l|}{ Adults Day 10} \\
\hline Control & $0.14(0.16)$ & $\mathrm{b}$ & $0.02(0.07)$ & $\mathrm{a}$ \\
\hline alpha-cypermethrin: & $1.0(0)$ & $\mathrm{d}$ & $1.0(0)$ & $\mathrm{b}$ \\
\hline \multicolumn{5}{|l|}{ B. bassiana F305: } \\
\hline low rate & $0.77(0.19)$ & $\mathrm{cd}$ & 0 & $\mathrm{a}$ \\
\hline med rate & $0.62(0.20)$ & $\mathrm{cd}$ & 0 & $\mathrm{a}$ \\
\hline high rate & $0.50(0.28)$ & c & 0 & $\mathrm{a}$ \\
\hline \multicolumn{5}{|l|}{ B. bassiana Beaugenic: } \\
\hline low rate & $0.089(0.20)$ & $\mathrm{a}$ & 0 & $\mathrm{a}$ \\
\hline med rate & $0.20(0.12)$ & $\mathrm{b}$ & $0.04(0.09)$ & $\mathrm{a}$ \\
\hline high rate & $0.383(0.35)$ & $\mathrm{b}$ & $0.06(0.11)$ & $\mathrm{a}$ \\
\hline \multicolumn{5}{|l|}{ spinosad: } \\
\hline $72 \mathrm{~g} / \mathrm{ha}$ & $1.0(0)$ & d & $0.792(0.21)$ & $\mathrm{b}$ \\
\hline $144 \mathrm{~g} / \mathrm{ha}$ & $1.0(0)$ & d & $0.938(0.15)$ & $\mathrm{b}$ \\
\hline $288 \mathrm{~g} / \mathrm{ha}$ & $1.0(0)$ & $\mathrm{d}$ & $1.0(0)$ & $\mathrm{b}$ \\
\hline
\end{tabular}


Table 3 Mortality (mean proportion $( \pm S E)$ ) of Paropsis charybdis larvae and adults in response to treatment in bioassay 2. Also shown is the P-value denoting the effect of treatment on mortality. Means sharing letters are not significantly different at $\mathrm{P}<0.05$ for adults and larvae, respectively.

\begin{tabular}{|c|c|c|c|c|}
\hline & \multicolumn{2}{|c|}{ Larvae Day 4} & \multicolumn{2}{|c|}{ Adults Day 14} \\
\hline Control & $0.27(0.08)$ & $\mathrm{b}$ & $0.11(0.07)$ & $\mathrm{a}$ \\
\hline Alpha-cypermethrin: & 1.0 & $\mathrm{a}$ & -1 & \\
\hline Spinosad & & & & \\
\hline $12 \mathrm{~g} / \mathrm{ha}$ & 1.0 & $\mathrm{a}$ & -1 & \\
\hline $24 \mathrm{~g} / \mathrm{ha}$ & 1.0 & $\mathrm{a}$ & $0.40(0.141)$ & $\mathrm{b}$ \\
\hline $48 \mathrm{~g} / \mathrm{ha}$ & 1.0 & $\mathrm{a}$ & $0.85(0.096)$ & c \\
\hline Spinetoram & & & & \\
\hline $12 \mathrm{~g} / \mathrm{ha}$ & 1.0 & $\mathrm{a}$ & -1 & \\
\hline $24 \mathrm{~g} / \mathrm{ha}$ & 1.0 & $\mathrm{a}$ & 1.0 & $\mathrm{~cd}$ \\
\hline $48 \mathrm{~g} / \mathrm{ha}$ & 1.0 & $\mathrm{a}$ & 1.0 & $\mathrm{~cd}$ \\
\hline $\mathrm{P}$-value & 0.001 & & 0.001 & \\
\hline
\end{tabular}

${ }^{1}$ Insufficient adult beetles were obtained so only larvae were tested for these rates.

and an interaction between them $(\mathrm{P}<0.001)$ on mortality of adult $P$. charybdis. At $24 \mathrm{~g} / \mathrm{ha}$ spinetoram was significantly more efficacious against adult $P$. charybdis than spinosad was (Table 3). Adults feeding in the $24 \mathrm{~g} /$ ha spinosad treatment were observed to stop moving for a number of days but then either died $(40 \%)$ or showed a recovery and resumed feeding $(60 \%)$ between days 10 and 14 .

\section{Bioassay 3}

The proportion of adult mortality was significantly affected by the spinetoram rate at day $14 \quad(\mathrm{P}<0.0001)$. Equation 1 fitted the dose response data well (Figure 1) and had a coefficient of determination $\left(R^{2}\right)$ of 0.87 . From this equation, the $\mathrm{LD}_{50}$ was determined to be equivalent to $13.15 \mathrm{~g}$ ai/ha.

\section{Bioassays 4 and 5}

There was no effect of $Y$. entomophaga on adult $P$. charybdis, with just one beetle $\left(1 \times 10^{8}\right.$ dose $)$ dying 5 days after treatment (data not shown). Mortality of larvae occurred more rapidly in the highest concentration of Y. entomophaga than the control with $73 \%$ of larvae dead in the highest concentration after 3 days (Figure $2 \mathrm{a}$ ).
As with the Y. entomophaga there was no effect of $B$. thuringiensis var tenebrionis on adults, with $P$. charybdis mortality not significantly different from the controls at any rate (data not shown). Mortality of larvae occurred rapidly at the high B. thuringiensis var tenebrionis rate with all larvae dead within 3 days. Mortality levels in the lower concentrations were not significantly different to the control (Figure 2b).

\section{DISCUSSION}

The most promising alternative product to alpha-cypermethrin of those tested was the newly released Sparta $^{\mathrm{TM}}$ (spinetoram). This showed not only control of $P$. charybdis larvae (as did all the products, Table 2), but also slow but reliable kill of adults (Figure 1). At the rate recommended to control larvae of eucalyptus leaf beetles in Australia (12 g ai/ha) additional nonlethal effects were observed in these bioassays on adults. These included falling from the foliage, and cessation of feeding, but not death. A higher rate would be required for operational certainty of adult mortality, probably closer to $30 \mathrm{~g}$ ai/ha (Figure 1). Death for first instar larvae was much more rapid than adults, usually within 2 days, with complete mortality by 4 days. Spinetoram 


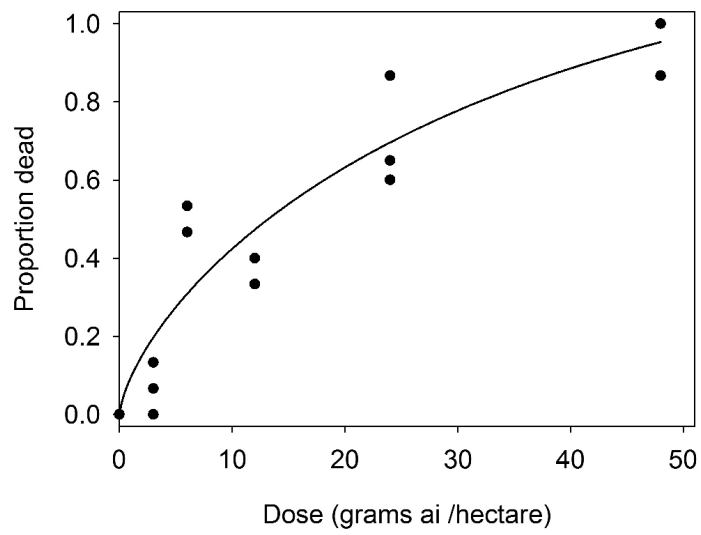

Figure 1 Relationship between adult $P$. charybdis mortality and dose of spinetoram (bioassay 3 ) 14 days after exposure. The following line was fitted to the data: $M=1.27(1-\exp (-0.0221 r))^{0.678}$; $\mathrm{P}<0.0001, R^{2}=0.87$.

potentially offers the first alternative to alphacypermethrin for the eucalyptus industry in New Zealand. However, this product is more expensive than alpha-cypermethrin, and is recommended to be applied with a high quality and also costly adjuvant. At the volumes and rates indicated by the results presented herein, a cost:benefit analysis needs to be undertaken to assess whether it is an economically viable option for eucalyptus plantations. Until this additional research is undertaken, a recommendation to use spinetoram for managing $P$. charybdis in eucalypts cannot be made. Important research would include assessing the impact of spinetoram on beneficial biological control agents that contribute to the suppression of $P$. charybdis in New Zealand, such as Neopolycystus insectifurax, Enoggera nassaui (Withers et al. 2011), generalist predators (e.g. Cleobora mellyi and Harmonia conformis) and predatory Hemiptera (Edwards \& Suckling 1980). Evidence is emerging that spinetoram shows far lower negative effects on many nontarget beneficial insects than its predecessor spinosad (Besard et al. 2011) and it is recommended that this be further evaluated in New Zealand.
One of the first products registered for use against eucalyptus leaf beetles in Australia was Success Naturalyte ${ }^{\circledR}$ (spinosad). Success Naturalyte ${ }^{\circledR}$ is registered in New Zealand for use against caterpillars, thrips and sawfly (Hymenoptera) larvae. This insecticide is made from spinosyn $\mathrm{A}$ and spinosyn $\mathrm{D}$, which are a chemical class of insecticides that work by contact and ingestion. Larvae take up to 3 days to die. When tested on P. bimaculata as an alternative to Bacillus thuringiensis (Novodor), results indicated spinosad was as effective as $B$. thuringiensis var tenebrionis in trials against young $P$. bimaculata larvae but was easier to apply (J.A. Elek, Forestry Tasmania, personal communication). In the present study spinosad was less effective than spinetoram against $P$. charybdis.

Several microbial insecticides have previously been tested in laboratory bioassays against $P$. charybdis: one strain of the bacterium B. thuringiensis var tenebrionis (variety San Diego) (Jackson \& Poinar 1989) and three isolates of B. bassiana (Hastuti et al. 1999). These were shown to be effective against larvae, and in the case of B. bassiana, pupae as well, but never on adult beetles. Of the three $B$. bassiana isolates tested by Hastuti et al. (1999), F305 ex BotaniGard showed the highest efficacy. That result was reflected in the present bioassays with F305 having the highest activity against larvae (Table 2). Paropsis charybdis adults showed significant resilience against these entomopathogens compared to some other eucalyptus foliage feeders. For instance adults of the weevil Gonipterus scutellatus sustained $100 \%$ contact mortality as well as $100 \%$ ingestion mortality from one particular strain of B. bassiana (strain PPRI 5339) (Echeverri Molina \& Santolamazza Carbone 2010). This finding had stimulated a further examination of the possibility of microbial insecticides for control of $P$. charybdis in New Zealand. The enterobacterium Yersinia entomophaga MH96 has shown promising activity against a range of insect pests (Hurst et al. 2011) and was an important product to also trial against $P$. charybdis. The present work has shown that, while there is 

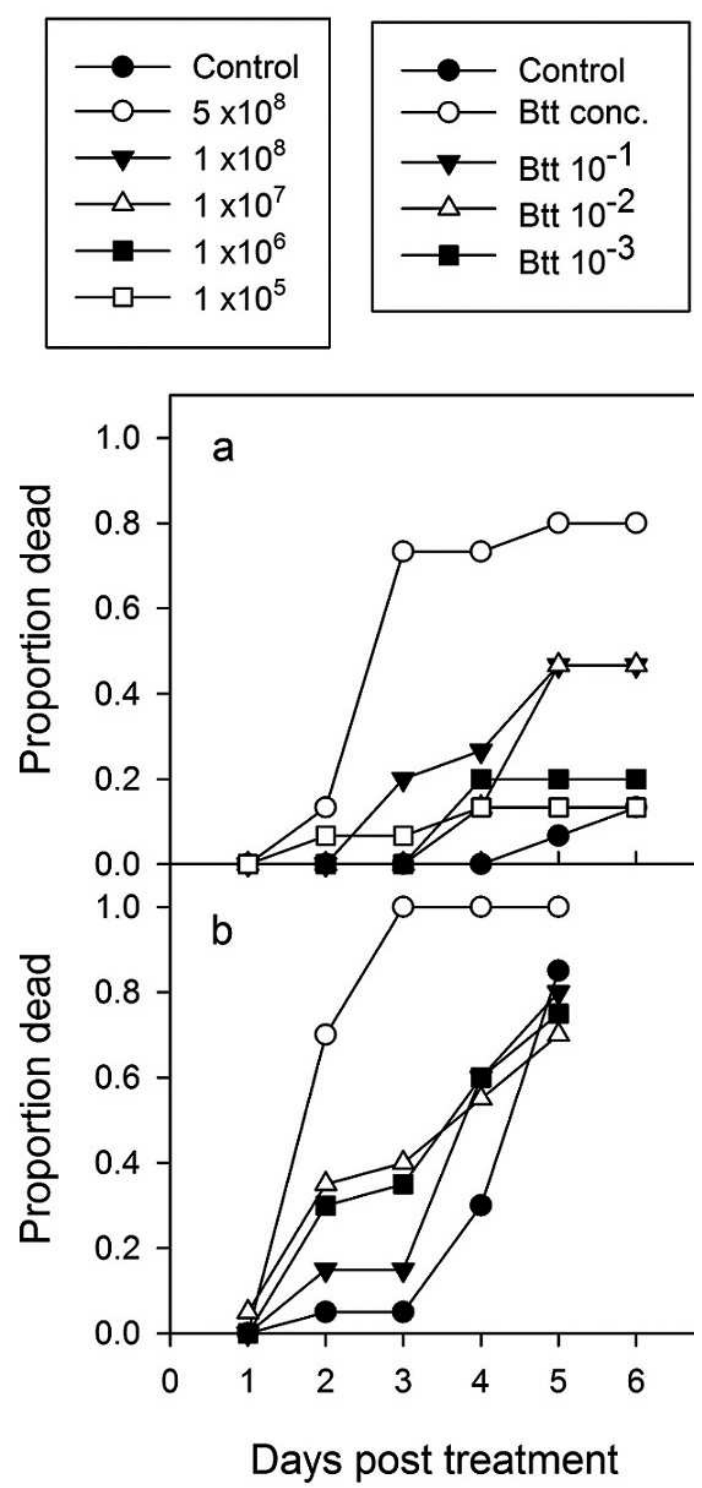

Figure 2 Mortality of $P$. charybdis larvae after exposure to different concentrations over time of (a) Y. entomophaga and (b) B. thuringiensis var tenebrionis (leaf dip bioassays 4 and 5). All SEs $\leq 0.114$ for both bioassays.

zero activity by $Y$. entomophaga against adults, this bacterium does induce mortality in larvae (Figure 2a). Despite an observed anti-feeding effect of Y. entomophaga against the larval stages and issues getting the bacterium to adhere to the leaf surface, mortality of around $70 \%$ against larvae for Y. entomophaga resulted.

After examining all potential microbial insecticides that are either in culture collections or under development in New Zealand, and trialling them against $P$. charybdis, no suitable microbial control agent could be identified for targeting both damaging life stages of this pest. It is now known that first instar larvae, but not adults, are susceptible to a range of biopesticides. Other studies have shown that some insects are more resistant to microbial pesticides in the adult stage, such as $L$. decemlineata where larval mortality after feeding on $B$. thuringiensis var tenebrionis decreased with increasing age (Stewart et al 1991), older mosquito larval stages were less susceptible to $B$. thuringiensis israelensis than younger larval stages (Wraight et al. 1981), and Spodoptera litura larvae were more susceptible to B. thuringiensis than adults (Zaz 1989). This phenomenon is attributed to several factors, such as metabolic differences and changes in gut cell composition (Glare \& O'Callaghan 2000).

From a forest management perspective, it is important to consider the question: "would a product active against larvae suffice?" Field trials have been conducted by Forestry Tasmania (Elek 1997; Beveridge \& Elek 1999; Elek \& Beveridge 1999) using the microbial insecticide Novodor, a commercial preparation of B. thuringiensis var tenebrionis. Novodor was shown to be moderately effective at controlling the larvae of the closely related eucalyptus beetle Paropsisterna bimaculata (Olivier), but to date it has been used only to control this pest in environmentally sensitive areas in Tasmania. Forestry Tasmania has a more widespread problem with eucalyptus leaf beetles in their plantations than New Zealand does, and many of the species attack the juvenile foliage. Field scouts are sent out into plantations to monitor the leaf beetle larval infestation rates in spring and summer, and when infestation exceeds a pre-determined threshold, sprays are undertaken (J.A. Elek, Forestry Tasmania, personal communication). It is suggested that 
this type of surveillance is not practical for managing leaf beetle infestations in New Zealand because $P$. charybdis larvae infest adult foliage at the very top of large trees. Various sampling methods for monitoring P. charybdis population dynamics have been trialled by researchers over many years (McGregor 1984; Murphy \& Kay 2000; Jones \& Withers 2003), but to date none has been cost-effective enough to up-scale to identify the optimum time to initiate insecticide applications. The timing of spray applications would have to be very tightly managed to kill the majority of larvae before they drop to the ground to pupate. Furthermore adult $P$. charybdis lay eggs over very long periods (Steven 1973; McGregor 1984), meaning larval sprays that failed to also kill reproductively active adults, would permit re-infestation to occur almost immediately. It is believed that the eucalyptus industry would be unable to economically justify spray operations targeting larvae alone, especially if more than one application was required per annum (S. Foster, Southwood Export Ltd, personal communication).

In conclusion, the New Zealand eucalypt plantation hardwood industry may benefit from finding an alternative to alpha-cypermethrin for managing $P$. charybdis, especially those managing plantations under FSC certification. With additional research, it may be that spinetoram is a product that holds some promise for this outcome.

\section{ACKNOWLEDGEMENTS}

Thanks to Robyn Gaskin (PPCNZ), Jane Elek (ForestryTas), Stefan Gous, Caro Gous, Liam Wright, Carol Rolando, Tracey Bates, Mitchell West, Belinda Gresham and Pam Taylor (Scion) for scientific and technical assistance. Thanks to Sue Zydenbos and Trevor Jackson (AgResearch), and to Travis Glare (Lincoln University) for supplying the Beauveria and Bacillus formulations. Crop Solutions/ Millenium Microbes supplied the Beaugenic, Dow Agrosciences supplied the Sparta. Thanks to Southwood Export Ltd, Carter Holt Harvey, Poronui Station, PF Olsen Ltd, C and M Bell and Hardwood Management Ltd for access to plantations. Thanks to Chikako van Koten (AgResearch) for statistical analysis of bioassays
4 and 5. This research was funded by Southwood Export Ltd, and the Future Forests Research Diverse Species programme, MBIE Core Funding to Scion, and the Yersinia research by MSI contract C10X0706 to AgResearch.

\section{REFERENCES}

Bain J 1977. Paropsis charybdis Stål (Coleoptera: Chrysomelidae). In: Forest and Timber Insects in New Zealand. Forest Research Institute and New Zealand Forest Service, Rotorua. 4 p.

Besard L, Mommaerts V, Abdu-Alla G, Smagghe $G$ 2011. Lethal and sublethal side-effect assessment supports a more benign profile of spinetoram compared with spinosad in the bumblebee Bombus terrestris. Pest Management Science 67: 541-547.

Beveridge N, Elek JA 1999. Bacillus thuringiensis var. tenebrionis shows no toxicity to the predator Chauliognathus lugubris (F.) (Coleoptera: Cantharidae). Australian Journal of Entomology 38: 34-39.

Echeverri-Molina D, Santolamazza-Carbone S 2010. Toxicity of synthetic and biological insecticides against adults of the Eucalyptus snout-beetle Gonipterus scutellatus Gyllenhal (Coleoptera: Curculionidae). Journal of Pest Science 83: 297-305.

Edwards PB, Suckling DM 1980. Cermatulus nasalis and Oechalia schellembergii (Hemiptera: Pentatomidae) as predators of Eucalyptus tortoise beetle larvae, Paropsis charybdis (Coleoptera: Chrysomelidae) in New Zealand. New Zealand Entomologist 7: 158-164.

Elek JA 1997. Assessing the impact of leaf beetles in eucalypt plantations and exploring options for their management. Tasforests 9: 139-154.

Elek J, Beveridge N 1999. Effect of a Bacillus thuringiensis subsp. tenebrionis insecticidal spray on the mortality, feeding, and development rates of larval Tasmanian Eucalyptus leaf beetles (Coleoptera: Chrysomelidae). Journal of Economic Entomology 92: 1062-1071.

FSC 2007. FSC Pesticides Policy: Guidance on implementation. www.fsc.org (accessed April 8 2013). 
Greener A, Candy SG 1994. Effect of the biotic insecticide Bacillus thuringiensis and a pyrethroid on survival of predators of Chrysophtharta bimaculata (Olivier) (Coleoptera: Chrysomelidae). Australian Journal of Entomology 33: 321-324.

Glare TR, O'Callaghan M 2000. Bacillus thuringiensis: Biology, ecology and safety. John Wiley and Sons Ltd, Chichester, UK. ISBN 0-471-49630-8.

Hastuti BS, Glare TR, Chapman RB 1999. Susceptibility of life stages of Paropsis charybdis to Beauveria bassiana. Proceedings of the $52^{\text {nd }}$ New Zealand Plant Protection Conference: 98-102.

Hurst MRH, Becher SA, Young SD, Nelson TL, Glare TR 2011. Yersinia entomophaga sp. nov. isolated from the New Zealand grass grub Costelytra zealandica. International Journal of Systematic and Evolutionary Microbiology 61: 844-849.

Jackson TA, Poinar GO, jr 1989. Susceptibility of Eucalyptus tortoise beetle (Paropsis charybdis) to Bacillus thuringiensis var. San Diego. Proceedings of the 42nd New Zealand Weed and Pest Control Conference: 140-142.

Jones DC, Withers TM 2003. The seasonal abundance of the newly established parasitoid complex of the Eucalyptus tortoise beetle (Paropsis charybdis). New Zealand Plant Protection 56: 51-55.

Loch AD 2005. Mortality and recovery of eucalypt beetle pest and beneficial arthropod populations after commercial application of the insecticide alpha-cypermethrin. Forest Ecology and Management 217: 255-265
McGregor PG 1984. Biology of Paropsis charybdis Stål (Coleoptera: Chrysomelidae), a Eucalyptus defoliator in New Zealand. PhD thesis, Massey University, Palmerston North. $100 \mathrm{p}$.

Murphy BD, Kay MK 2000. Paropsis charybdis defoliation of Eucalyptus stands in New Zealand's central North Island. New Zealand Plant Protection 53: 334-338.

Stewart JG, Lund JE, Thompson LS 1991. Factors affecting the efficacy of Bacillus thuringiensis var san diego against larvae of the Colorado potato beetle. Proceedings of the Entomological Society of Ontario 122: 21-25.

Steven D 1973. The host-plant relationships of Paropsis charybdis Stål (Coleoptera: Chrysomelidae). $\mathrm{PhD}$ thesis, University of Canterbury, Christchurch, New Zealand. 301 p.

White TCR 1973. The establishment, spread and host range of Paropsis charybdis Stål (Chrysomelidae) in New Zealand. Pacific Insects 15: 59-66.

Withers TM, Phillips LD, Bates TEM, Ganley RJ 2011. Hybridisation between populations of Enoggera nassaui in New Zealand. New Zealand Plant Protection 64: 44-48.

Wraight SP, Molloy D, Jamnback H, McCoy $\mathrm{P}$ 1981. Effects of temperature and instar on the efficacy of Bacillus thuringiensis var. israelensis and Bacillus sphaericus Strain 1593 against Aedes stimulans larvae. Journal of Invertebrate Pathology 38: 78-87.

Zaz GM 1989. Effectiveness of Bacillus thuringiensis Berliner against different instars of Spodoptera litura (Fabricius). Indian Journal of Entomology 45: 201-202. 